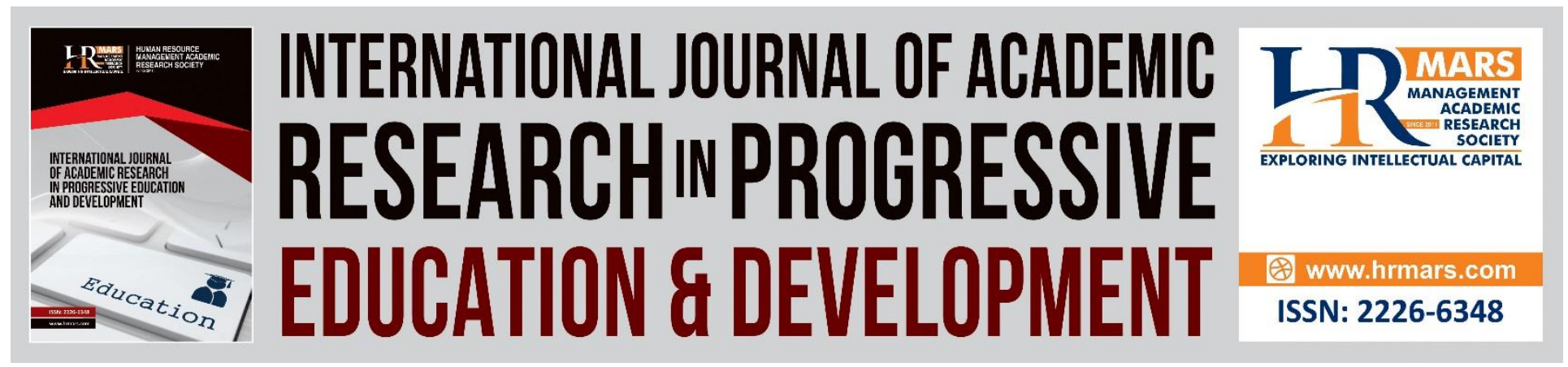

\title{
Teachers' Perspective on Cultural Diversity in School: A Case Studies
}

Norwaliza Abdul Wahab, Pechi Nathan, Nor Hasnida, Che Md Ghazali, Norfishah Mat Rabi, Amir Hasan Dawi

To Link this Article: http://dx.doi.org/10.6007/IJARPED/v7-i3/4568 DOI: $10.6007 /$ IJARPED/v7-i3/4568

Received: 02 June 2018, Revised: 24 June 2018, Accepted: 03 July 2018

Published Online: 20 July 2018

In-Text Citation: (Wahab et al., 2018)

To Cite this Article: Wahab, N. A., Nathan, P., Hasnida, N., Ghazali, C. M., Rabi, N. M., \& Dawi, A. H. (2018). Teachers' Perspective on Cultural Diversity in School: A Case Studies. International Journal of Academic Research in Progressive Education and Development, 7(3), 497-506.

Copyright: (C) 2018 The Author(s)

Published by Human Resource Management Academic Research Society (www.hrmars.com)

This article is published under the Creative Commons Attribution (CC BY 4.0) license. Anyone may reproduce, distribute, translate and create derivative works of this article (for both commercial and non-commercial purposes), subject to full attribution to the original publication and authors. The full terms of this license may be seen

at: http://creativecommons.org/licences/by/4.0/legalcode

Vol. 7, No. 3, July 2018, Pg. 497 - 506

http://hrmars.com/index.php/pages/detail/IJARPED

JOURNAL HOMEPAGE

Full Terms \& Conditions of access and use can be found at http://hrmars.com/index.php/pages/detail/publication-ethics 


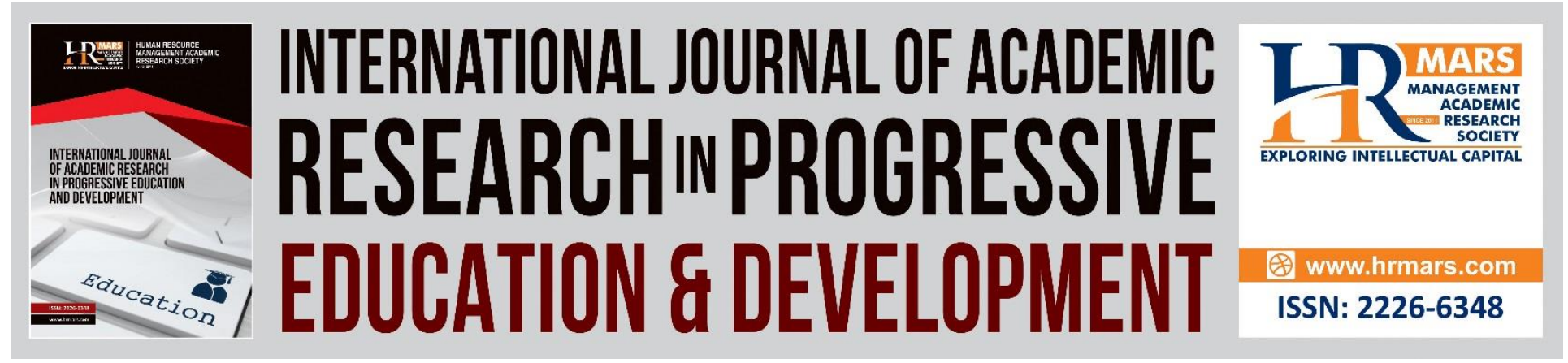

\title{
Teachers' Perspective on Cultural Diversity in School: A Case Studies
}

\author{
Norwaliza Abdul Wahab, Pechi Nathan, Nor Hasnida, Che Md \\ Ghazali, Norfishah Mat Rabi, Amir Hasan Dawi
}

Faculty of Human Development, Universiti Pendidikan Sultan Idris, 35900 Tanjung

Malim, Malaysia.

\begin{abstract}
Malaysia is known as a multi-racial and multi-cultural. The many different ethnicities that currently exist in Malaysia have their own unique and distinctive cultural identities. This study aims to understand teachers' perspective on cultural diversity in primary schools based on Byram's multicultural model that focused on four aspects which are knowledge, skills, attitudes and practices. A qualitative approach with case study design was used in this study. The respondents involving three teachers and an administrator in an elementary school in Perak selected by purposive sampling. Instruments used was the interview's protocol, observation's check list and documents analysis. The findings showed that the respondents have the knowledge, skills, openness attitudes and practice towards other cultures. This study has shown that teachers with positive attitude towards cultural diversity and correlating cultural diversity allow the three largest ethnic groups in Malaysia to have their respect and accepting the cultural diversity that exist in this country. It also can be a guidance for the department of education in drafting a new program related to cultural diversity in schools. Hence, it can also be used as a guideline by other researchers in the future.

Keywords: Teacher's Perspective, Cultural Diversity, School, Byram's Model, Case Studies.
\end{abstract}

\section{Introduction}

Generally, multiculturalism is a uniformity of culture in the community. The term 'multiculturalism' refers to "the complex range of issues associated with cultural and religious diversity in a society, and the social management of the challenges and opportunities such diversity offers" (Nye, 2007 p. 110). The community includes interaction, tolerance and integration. In short, multiculturalism is a fact that must be accepted and understood positively to the development of culture. The cultural diversity of the community consists of people who are made up of diverse ethnic and cultural diversity but to live together. The life of their communities is not based on a single culture or a closed system but based on the values of the range. Cultural diversity is the cornerstone of this research because it involves teachers of the 
Vol. 7, No. 3, July 2018, E-ISSN: 2226-6348 @ 2018 HRMARS

three largest ethnic groups in Malaysia, each of which plays an important role in all aspects. Malaysia, which is a developing country, located in Southeast Asia and it has a total population of over 26 million people of various ethnicities and religions. According to Ibrahim et al. (2011), the major ethnic groups are Malays (50.3\%), Chinese $(23.8 \%)$, non-Malay indigenous people (11.0\%) and Indians (7.1\%) Malaysian multicultural society is often defined in terms of ethnicity and religious plurality (Zaid Ahmad, 2007).

Supardan (2001) stated the values of culture can be described in three forms, namely the acceptance of ethnic and culture of a nation by looking at the cultural ancestry in connection with ethnic origin and civilization, both studying history, lifestyle, arts, literature and contributions to ethnic described in detail and the third studies the development of ethnic culture of today include customs, food, family interaction, values and others. Education is capable in functioning as a channel for improving the relationship between individuals. School can be a medium for the students to process their socialisation and allow them to expand their understanding perspective , sight and responses towards something (Abd. Rahim Abd. Rashid., 2001). By having understanding and positive perception among cultures, a harmonius nation can be produced. In the other hand, a deep understanding of the teachers on cultural diversity is vital as they are the responsible persons in changing the school environment that brings reflect of the cultural diversity in the classroom and society.

\section{Problem Statement}

Teachers' knowledge on cultural diversity is important in ensuring that the learning process is not influenced by prejudice. Teachers can adopt or use a fairer and more appropriate skills of their pupils' culture or ethnic background. Rifai (2007) which states that the conflicts within society often occurs along with the unwillingness of the public members trying to understand and appreciating the diversity of ones culture. Issues related to ethnic preferences and demands, sometimes inter-ethnic and at other times intra-ethnic, remain crucial in multicultural Malaysia (Ibrahim, 2007).

There are efforts taken by the responsible parties to improve skills and expanding the practice of cultural diversity in the Malaysian education system and it is still remains in order to produce pupils with understanding and respect towards culture of the nations. In fact, they are also promoting cultural diversity as an agent of the consolidation of the nation needed to enhance knowledge, skills that can change attitudes and practices in the current education in this country. This study was conducted to provide a focus for the inquiry problems and issues related to cultural diversity. Cultural diversity is important in the Malaysian education system as the students are of various ethnic and cultural backgrounds and multicultural education concept is still new in the context of the Malaysian education system. Currently, the curriculum and cocurricular activities related to cultural diversity are lacking in schools. Knowledge and skills about cultural diversity among teachers are seen as something new and poorly understood and applied in the process of teaching and learning. The researcher believes that some effort and planning must be implemented in various stages of the education system, so that teachers can be provided with the skills and knowledge sets in parallel with the situation in schools and to fulfil the wishes of the country. 
The researchers studying multiculturalism found that teachers are less exposed to this concept so did the school system. These affect their teaching and learning activities in the classroom. Some approaches need to be adopted for example, the objectives of each subject should be introducing element of cultural diversity to make this happened. The practice of education through curriculum and co-curriculum should emphasise other ethnic cultures too. It is important to raise awareness of cultural diversity among teachers in the country and the role of schools as agents of change and community development.

According to Yusof (2005), the establishment of a country that contains a variety of ethnic groups needs unity and cooperation in politics, economy and strong social and cohesive. Ethnic unity can only be achieved through social interaction. The greater social interaction is formed between the strengthening ethnic unity and understanding of the people in the country. Social interaction among people can determine the stability of the political, social, economic and welfare. Social interaction is also important aspect in the construction of identity, particularly among plural society such as Malaysia.

\section{Research Objective}

In particular, this study is to meet the following objectives:

i) Identify the knowledge of teachers in primary schools on cultural diversity.

ii) Identify the skills of teachers in the implementation of cultural diversity.

iii) Examining the attitudes of teachers towards multiculturalism. iv) Examining the practice of teachers in implementing elements of cultural diversity. 


\section{Conceptual Framework}

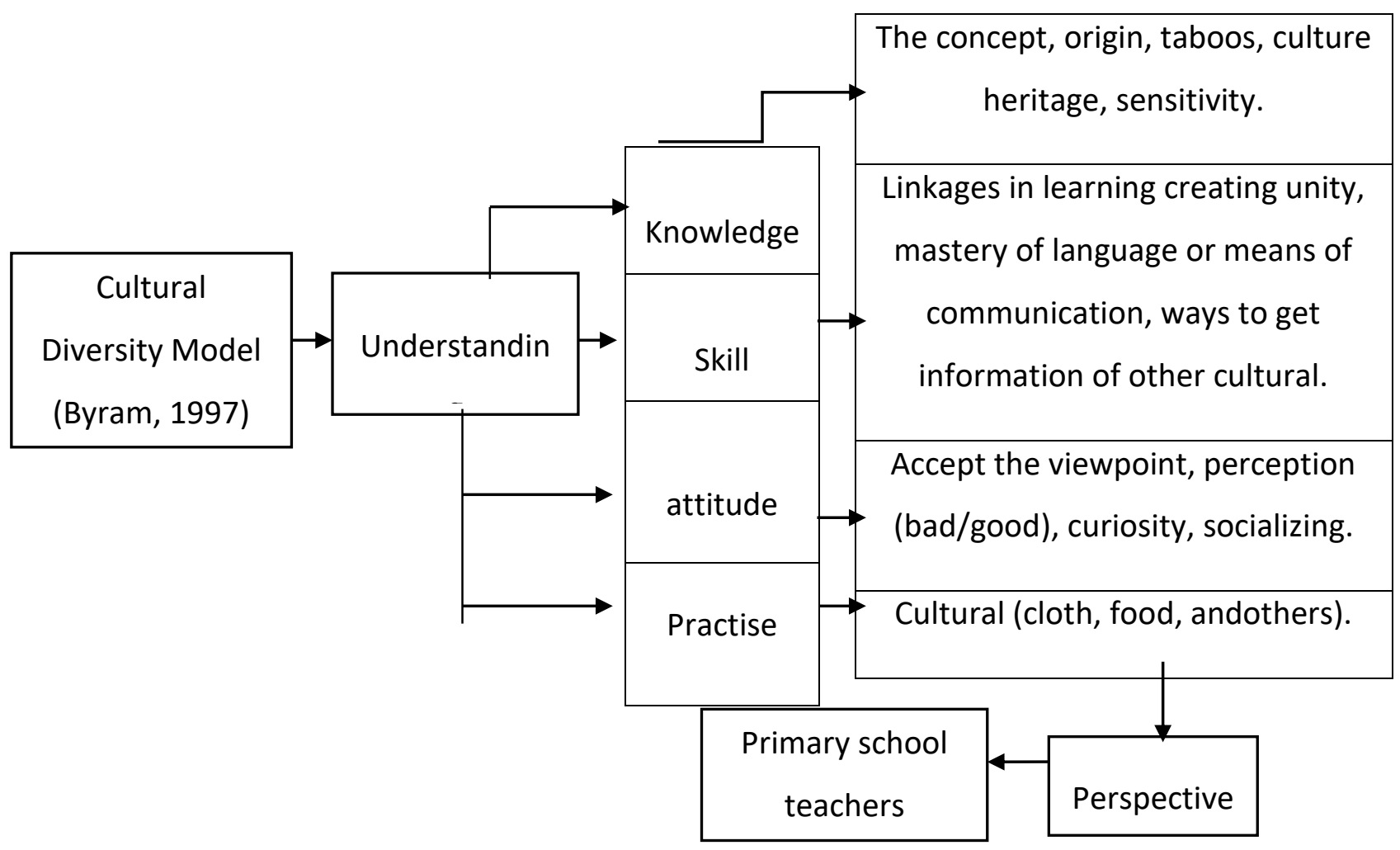

Figure1: Conceptual Framework ofTeacher's Perspective on Cultural Diversity

\section{Methodology}

The design of this study is qualitative involving 3 teachers of different races, namely Malay, Chinese, Indian and Malay an administrator in the elementary school. Descriptive qualitative data, in the form of words spoken or written about human behaviour that can be observed (Jasmi, 2012). The research design will ensure that the information obtained is consistent, with the research questions to be observed. The information obtained should use the most effective method (Konting, 2005).

This study used a semi-structured interview technique. A semi-structured interview is similar to structured interviews, the questions to be submitted will be drafted first. In addition, researchers also interviewed the administrator of Headmaster at the school, inquiry through brief interviews to see whether it supports or not, parallel or not to interview the respondent data. According to Idris (2013), interviews give accurate data as well as researchers and study participants may get the idea during an interview. According to Lebar (2006) interview method is very useful for inquiring about past events that people experience difficult to replicate again. The next instrument is observation form. Through the observation of researchers collecting structured data based on observed behaviour, where behavior-behavior that is listed in the form of 
Vol. 7, No. 3, July 2018, E-ISSN: 2226-6348 @ 2018 HRMARS

observation. According to Idris (2013) observation method is often used when researchers tried to investigate the norms, values, and purpose implicit in the subject being investigated. Next, the instrument is a document. Researchers have collected a copy of a summary of the teaching respondents involved to see whether they apply or not cultural diversity in teaching and learning. According to Idris (2013) also, case studies using a variety of methods to collect data, which is mainly interviews, observations and material of document.

\section{Research Framework}

Rajah 2: A research framework design that has been used by researchers in this study:

\begin{tabular}{|l|l|l|}
\hline $\begin{array}{l}\text { Interview Question : Transcription } \\
\text { of the interview. }\end{array}$ & \multicolumn{1}{|c|}{ Observation:Obcervation } \\
\cline { 2 - 3 } checklist
\end{tabular}

Figure 2: Research Design

\section{Sample}

According to Chua (2006), purposive sampling refers to sampling procedure in which a group of subjects that have certain characteristics chosen as respondents. This led to other subjects in the study population did not have the opportunity to be selected as respondents. This is because the study relates to the perspective of cultural diversity among teachers of Malay, Chinese and Indian primary schools, the subject of which represent the only individual who has been selected to participate in this study. In this study, three teachers of Malays, Chinese, Indians and Malays are an administrator of a primary school in the district of Larut Matang and Selama, Perak had been selected. Through the selection of the sample of this study, the researchers intend to examine some relevant aspects such as knowledge, skills, attitudes and practices of teachers on cultural diversity.

\section{Research Scope}

The study involved only three teachers and an administrator of an elementary school in the district of Larut Matang and Selama, Perak. Idris (2008), qualitative research sample different from the quantitative as qualitative research sample selected purposively. He added that research subjects were selected based on the criteria established in accordance with the problems to be studied. So, in this study the three teachers and an administrator as the subject 
Vol. 7, No. 3, July 2018, E-ISSN: 2226-6348 @ 2018 HRMARS

that meets the criteria established for this study. Each representing Malays, Chinese and Indians. Thus, they are selected to participate in this study. The analysis is based on the definition set out in the operational definition. This study is intended to examine the perspective of cultural diversity among teachers of various ethnic groups in the primary.

\section{Result and Discussion}

Results showed four aspects of teachers' perspective on cultural diversity in schools, knowledge of diverse cultures, skills of teachers in the implementation of multiculturalism, the attitude of teachers towards multiculturalism and the practice of teachers in implementing elements of cultural diversity.

\section{Knowledge of the Cultural Diversity}

Knowledge is any useful information for the task being performed and the incorporation of detergent and semantic set that can be used to describe something, (Baharuddin 2014). Knowledge is defined as a clear perception about something, understanding, learning, practical experience, skills, identification, collection of information arranged that can be used to solve problems, habits of language, concepts, ideas, facts, relationships between facts, information, and the ability to use all this in modeling different aspects of the environment. Elements of knowledge in this research focus on several aspects as recommended by Byram (1997), the knowledge of the social group, understand practice and interaction in society includes understanding the culture of every community, know the origin of a culture, to accept the reality of cultural diversity, acting in accordance follow the culture and language in their daily interactions.

The researchers found these teachers' knowledge regarding cultural diversity can be said to be high compared to normal people. Some of the questions that have been put forward to determine the respondents' knowledge are related to cultural diversity and have been accepted well by them. Moreover, the answers were given by the respondents to answer the research questions related to their knowledge regarding cultural diversity. In addition, the overall observations made in view of these respondents also showed good results where they have a pretty good basic knowledge about the diversity of this culture. Respondents were also using their basic knowledge regarding cultural diversity in teaching and learning as well as enable their students to appreciate the diversity of cultures in Malaysia. In fact, the administrator also gave a positive outlook on her teachers where he could see them all day knowledge either in terms of mixing or application in teaching and learning.

\section{Skills of Teachers in the Implementation of the Cultural Diversity}

The skills of teachers in the implementation of cultural diversity both in terms of mixing or application in teaching were also investigated by model Byram and also from the perspective of the researcher. Some skills have been recommended by Byram (1997), the skills product knowledge of other cultures, other cultural skills correlate with its own culture, ability to generate knowledge, attitudes and skills in communication and openness. Trading Instrumentsstudy also has to do with continuity and skill and Byram model has been suggested. It is used as an important guide for researchers in the search of answers to any questions that arise. Based 
Vol. 7, No. 3, July 2018, E-ISSN: 2226-6348 @ 2018 HRMARS

on interviews that have been conducted, almost all respondents respectively have skills in association with teachers from various ethnic groups. In addition, they also apply elements of multiculturalism in their subjects. In addition, the observation can also be concluded that the respondents have multicultural skills and apply their skills in teaching and learning in the classroom. Analysis documents of the findings reinforce both Trading Instruments interviews and observations, which, when examined plans to teach respondents found that they made it clear how they relate teaching and learning in the classroom with cultural diversity. In fact, several activities carried out are comprehensive on cultural diversity. Yusof (2005), stating that the requirements of cultural diversity in the education system from various aspects, namely the relationship between students, teachers, parents and the community and interpersonal and intrapersonal relationships that are central to the educational process.

\section{The Attitude of Teachers Towards Multiculturalism}

Attitudes toward cultural diversity are also expressed in Byram model of openness and attitude practised in communication and interaction. The respondents of this study are aware that their attitude is one of the things that are important in a situation that has a diversity of cultures. Since the school used for this study are covered by multiracial teachers as the respondents found to show an open and positive attitude towards multiculturalism. Analysis of interviews, observations and document also explain that this attitude of teachers towards cultural diversity is good and it helps to create a harmonious atmosphere of the school. In addition, it is important for them reflecting to the cultural diversity attitude in the classroom so that the elemets of multicultural in teaching and learning would be applied. It symbolises their positive attitude towards exposing their students to the cultural diversity that exists in Malaysia. Diversity and difference are not a factor to be divided and hostile (Buang, Musa \& Hidayat, 2011), even supposed to where they know, mingle with each other and helping each other so that the peace and prosperity coexistence can be achieved.

\section{The practice of teachers to cultural diversity}

Respondents of this study not only accept the cultural diversity that exists in their school even they adopt elements of cultural diversity as a way of life. For example, when asked about the practice of wearing clothes other cultures, all respondents indicated that they used to wear traditional clothes as well as those of other communities still practice it. Also in terms of food, they said that they always try the traditional food of other races and they will love these foods. The respondents also indicated that the practice of other cultures is not wrong if it's done in a proper way, especially not in violation of the rules of ethics and religion. The observations also show that respondents have adopted traditional costumes of other races and they are trying the food of other races. In fact, the observations also found that they did not feel any differences practicing other cultures and demonstrate their familiarity with cultural diversity.

\section{Conclusion}

An understanding of cultural diversity plays an important role in creating an atmosphere of harmony and ensure that school of excellence as a result of the combined power of all of the school community. The findings showed that all respondents have an understanding in terms of knowledge, an understanding of multicultural skills, know to demonstrate appropriate in the 
Vol. 7, No. 3, July 2018, E-ISSN: 2226-6348 @ 2018 HRMARS

circumstances, as well as the practice of cultural diversity in life. According to their understanding, they have found a positive perspective in terms of knowledge, skills, attitudes and practices of multiculturalism. Arshad, Othman \& Awang Da (2011) in their study of multicultural literature role in the formation of a national unity Malaysia has stated that the issue of unity among the various races is not easily addressed by the head of the country. The values of tolerance among different communities who practice a different culture are not easily etched in the hearts of young people if it is not applied from the beginning again. So schools should play a role in implementing the values of tolerance and understanding in subjects related to humanities subjects such as language and literature. Through these subjects values of mutual respect and understanding between races can be confirmed easily in the subject. Through materials such as literature, multicultural values are crucial in fostering unity can be planted in the hearts of young people in Malaysia with a variety of effective teaching strategies. So, as educators in this era of modernity, we do not have focused on the student's academic achievement simply by ignoring the implementation of the humanity within them. Students should balance the various aspects along with the establishment of the national education philosophy Malaysia Malaysia where education is to produce students who are balanced in terms of physical, emotional, spiritual, intellectual and social. The social element is one of the things that have been given priority in the philosophy of education in Malaysia to produce a student who is balanced in terms of social. So, cultural diversity is one important aspect of the situation in Malaysia. Therefore, a teacher must be an expert in cultural diversity in terms of knowledge, skills, attitudes and cultural practices of another people.

\section{References}

Abd. Rahim Abd. Rashid. (2001). Nilai-nilai murni dalam pendidikan: Menghadapi perubahan dan cabaran alaf baru. Utusan Publications.

Arshad, M., Othman, A. J., \& Awang Da, N. (2011). Peranan kesusasteraan pelbagai budaya dalam pembentukan perpaduan kebangsaan di malaysia. Masalah pendidikan, 34, 81-98.

Baharuddin, A. (2014). Amalan penyeliaan pensyarah pembimbing terhadap pelaksanaan latihan industri di Politeknik Sultan Haji Ahmad Shah Kuantan, Pahang (Doctoral dissertation, Universiti Tun Hussein Onn Malaysia).

Buang, N. M., MUSA, N. Y., \& HIDAYAT, A. (2011). Hubungan etnik di malaysia dari perspektif islam. Kajian malaysia, 29(1), 1-28.

Byram, M. (1997). Teaching and assessing intercultural communicative competence. Multilingual matters.

CHUA, Y.P. (2006). KAEDAH PENYELIDIKAN EDISI PERTAMA. MC GRAW HILL EDUCATION.

Ibrahim, R. (2007). Multiculturalism and education in Malaysia. Culture and Religion, 8(2), 155167.

Ibrahim, R., Muslim, N., \& Buang, A. H. (2011). Multiculturalism and higher education in Malaysia. Procedia-Social and Behavioral Sciences, 15, 1003-1009.

Idris, F. (2008). Persampelan dan kaedah kutipan data.

http://researchipbmm2008.blogspot/2008/01pesampelan-dan-kaedah-kutipan-data.html.

Retrieved on 13 Sep 2016

IDRIS, N. (2013). PENYELIDIKAN DALAM PENDIDIKAN. MCGRAW-HILL EDUCATION. 
INTERNATIONAL JOURNAL OF ACADEMIC RESEARCH IN PROGRESSIVE EDUCATION AND

DEVELOPMENT

Vol. 7, No. 3, July 2018, E-ISSN: 2226-6348 @ 2018 HRMARS

Jasmi, K. A. (2012). Penyelidikan kualitatif dalam sains sosial. Kursus penyelidikan kualitatif siri 1 2012, 1-11.

Konting, M. M. (2000). Research methods in education. Kuala lumpur: dewan bahasa dan pustaka.

Lebar, O. (2006). Penyelidikan kualitatif: Pengenalan kepada teori dan metod. Penerbit Universiti Pendidikan Sultan Idris.

Nye, M. (2007). The challenges of multiculturalism. Culture and Religion - An Interdisciplinary Journal, Vol. 8 Number 2, 109-124.

Rifai, A. (2007). Perpustakaan dan pendidikan multikulturalisme. Media pustakawan I 4 (2): 3742.

Supardan, D. (2001). Pendidikan multibudaya. Bandung: universitas pendidikan indonesia.

Yusof, N. M. (2005). Multicultural education practice among teachers in national secondary schools: A case study in Kedah. Malaysian Jounal of Educators and Education, 20, 97-111.

Zaid Ahmad, Z. (2007). Multiculturalism and religio-ethnic plurality: the Malaysian experience. Culture and Religion, 8(2), 139-153. 